ZuZanna Benincasa

Uniwersytet Warszawski

\title{
OD 'RES NULLIUS’ DO ‘FRUCTUS FUNDI’. UPOLOWANA ZWIERZYNA ORAZ ZYSKI Z POLOWANIA I POŁOWU JAKO POŻYTEK Z GRUNTU W ROZWAŻANIACH RZYMSKICH JURYSTÓW
}

Problematyka uznania dzikich zwierząt oraz zysków z polowania i połowu za fructus fundi, a więc pożytek, jaki przynosi grunt, w pismach rzymskich jurystów jest bezpośrednio związana z zagadnieniami dotyczącymi służebności użytkowania i granic, w których użytkownik mógł korzystać z przysługującego mu prawa do uti frui, jako prawa rzeczowego pozwalającego na czasowe korzystanie z rzeczy i pobieranie z niej pożytków w sposób ograniczony w zasadzie jedynie poprzez wymóg zachowania integralności fizycznej rzeczy (salva eorum substantia). Rozważania rzymskich iurisprudentes dotyczące kwalifikacji konkretnych korzyści pozyskiwanych przez użytkownika i swobody korzystania z przysługującego mu prawa były bowiem uwarunkowane koniecznością wyznaczenia granic jego wolności w korzystaniu z rzeczy obciążonej służebnością i stanowiły wyraz dążenia do wypracowania rozsądnego kompromisu między potrzebą maksymalizacji dochodów pozyskiwanych z rzeczy przez użytkownika a ochroną uprawnień właściciela rzeczy zainteresowanego odzyskaniem rzeczy w stanie niepogorszonym po wygaśnięciu służebności.

Odejście od czysto naturalistycznej koncepcji pożytku, którego konsekwencją było odrzucenie tradycyjnych atrybutów fructus, jakimi były regularność i systematyczność ich pozyskiwania przy zachowaniu 
zdolności reprodukcyjnej rzeczy macierzystej i bezpośrednia zależność między korzystaniem z rzeczy a ich pozyskiwaniem, doprowadziło do uznania za fructus fundi wszystkiego, co rodzi się na gruncie i co może być $\mathrm{z}$ gruntu uzyskane $\mathrm{w}$ toku jego eksploatacji zgodnie z kryterium boni viri arbitrium, a także wypracowania koncepcji pożytku rozumianego jako dochód, czysty zysk z rzeczy (frugem pro reditu apellari) ${ }^{2}$. W tym kontekście przedmiotem zainteresowania rzymskich jurystów stają się nie tylko dzikie zwierzęta, ptactwo i ryby, które użytkownik mógł chwytać na użytkowanym gruncie, lecz także dochód, jaki mógł on uzyskać ze sprzedaży czy wynajmu takich zwierząt albo prawa do polowania czy połowu.

W odniesieniu do możliwości potraktowania jako fructus fundi dzikich zwierząt żyjących w stanie naturalis libertas na gruncie oddanym w użytkowanie, in primis należy odwołać się do ogólnej zasady, zgodnie z którą omnia quae terra mari caelo capiuntur stanowiły część natury i nie należały do nikogo, a ich własność mógł nabyć każdy przez zawłaszczenie (occupatio), bez względu na to, czy polował na własnym gruncie czy na cudzym, i niezależnie od zgody udzielonej przez właściciela tego gruntu na polowanie czy połów ${ }^{3}$.

2 Na temat ewolucji koncepcji fructus fundi por. przede wszystkim R. CARDILLI, La nozione giuridica di 'fructus', Napoli 2000.

3 G. 2,67; D. 41,1,1,1; D. 41,1,3,2; D. 41,1,5 pr. Na temat zawłaszczenia dzikiej zwierzyny por. G. LOMBARDI, Libertà di caccia e proprietà privata in diritto romano, «BIDR» 12-13/1948, s. 273-343; M.J. GARCÍA GARRIDO, Derecho à la caza y 'ius prohibendi' en Roma, "AHDE» 26/1956, s. 269-336; G. Polara, Le venationes. Fenomeno economico e costruzione giuridica, Milano 1983, w szczególności s. 39, przyp. 49; 64-71; Ch. Donahue Jr, Animalia ferae naturae: Rome, Bologna, Leyden, Oxford and Queens County N.Y., [w:] Studies in Roman Law in Memory of A. Arthur Schiller, Leiden 1986, s. 39-63; A.D. MANFREDINI, „Chi caccia e chi è cacciato”. Cacciatore e preda nella storia del diritto, Torino 2006, s. 13-25; M. Polojac, Gaius, Hadzic and 'occupatio' of wild animals - classical Roman law in the Serbian Civil Code, [w:] R. VAN DEN BERGH et al., 'Meditationes de iure et historia'. Essays in honour of Laurens Winkel, «Fundamina» 20.2/2014, s. 739-741; Z. BENINCASA, 'Occupatio’ jako sposób nabycia własności dziko zyjących zwierząt w prawie rzymskim, «Studia Iuridica» 59/2014, s. 9-39, w szczególności s. 19-20; EADEM, 'Illud quaesitum est, an fera bestia, quae ita vulnerata sit, ut capi possit, statim nostra esse intellegatur'. Zagadnienie ustalenia momentu zawłaszczenia dzikiego zwierzęcia w rozważaniach rzymskich jurystów u schyłku republiki, [w:] D. MALEC, 
Wspomniana wyżej zasada, definiowana w literaturze romanistycznej jako wolność polowania ${ }^{4}$, wydaje się zatem wykluczać możliwość potraktowania dzikiej zwierzyny, ptaków i ryb jako fructus fundi, bowiem dzikie zwierzęta bytujące na gruncie w stanie naturalis libertas stanowiły część natury i nie były uznawane za należące do właściciela gruntu. Jako res nullius podlegające zawłaszczeniu, których obecność na gruncie miała charakter incydentalny i okazjonalny, nie były uważane za rzeczy prawnie czy funkcjonalnie powiązane z samym fundus, do których prawo miałoby przysługiwać właścicielowi gruntu czy też jego użytkownikowi.

Zasada ta, mająca swoje korzenie w okresie archaicznym, kiedy to dzikie zwierzęta stanowiły przede wszystkim zagrożenie dla człowieka

Ł. Marzec, T. Palmirski, 'Semper fidelis'. Prace dedykowane pamięci Profesora Janusza Sondla legendzie krakowskiego fakultetu prawniczego, Kraków 2017, s. 43-58.

4 Pomimo że właściciel gruntu mógł w ramach przysługującego mu ius prohibendi zakazać wstępu na teren swojej nieruchomości, nie miał on prawnej możliwości zapobiec zawłaszczeniu dzikiej zwierzyny przez osoby trzecie, które bezprawnie wtargnęły na jego posiadłość z zamiarem kłusowania. Należy jednak wyraźnie podkreślić, że uznanie dziko żyjących stworzeń za res nullius możliwych do zawłaszczenia nie uprawniało jednak myśliwego czy rybaka do samowolnego wtargnięcia na teren cudzej nieruchomości i naruszania własności i posiadania osoby trzeciej, umożliwiając mu jedynie nabycie własności schwytanego w konsekwencji takiego działania zwierzęcia, ptaka czy złowionej ryby. Tym samym wolność polowania na dziko żyjące zwierzęta powinna być w prawie rzymskim interpretowana przede wszystkim jako możliwość zawłaszczania omnia quae terra mari caelo capiuntur, niezależnie od miejsca ich schwytania, a nie jako bezwzględne prawo do polowania czy łowienia ryb zarówno na gruncie własnym, jak i cudzym, a priori zapewniające całkowitą bezkarność osobie naruszającej własność osoby trzeciej poprzez wtargnięcie na cudzy grunt i polowanie czy łowienie ryb na tymże gruncie. Por. G. Lombardi, op. cit., s. 272-343; M.J. García GARrido, op. cit., s. 269-336; G. Polara, op. cit., s. 9-17; L. Amirante, recenzja z G. Polara, Le 'venationes'. Fenomeno economico e costruzione giuridica, «Iura» 34/1983, s. 255-262; R. MARTINI, Sui frutti delle'venationes', «Labeo» 32/1986, s. 215-218; O. Longo, Le regole della caccia nel mondo greco-romano, "Aufidus» 1/1987, s. 59-91; A.D. MANFrEDINI, „Chi caccia e chi è cacciato"..., s. 32-37; IDEM, Un' iniuria' che non c'è, [w:] Diritto romano, tradizione romanistica e formazione del diritto europeo, red. L. VACCA, Milano 2008, s. 181-202; Z. BENINCASA, Alcune riflessioni sulla libertà di caccia nel diritto romano: vivai e riserve di caccia, [w:] 'Mater familias'. Scritti romanistici per Maria Zabłocka, red. Z. Benincasa, J. URBAnik, Warszawa 2016, s. 39-62. 
oraz jego upraw i hodowli, u schyłku republiki, pod wpływem zmian rzeczywistości społeczno-gospodarczej, zaczyna stawać się coraz bardziej anachroniczną i nieuwzględniającą nowego kontekstu ekonomicznego. $\mathrm{W}$ tym okresie, w związku z rosnącym popytem na dzikie zwierzęta dla celów kulinarnych i rozrywkowych ${ }^{5}$, stają się one źródłem potencjal-

5 Na atrakcyjność hodowli dzikich zwierząt wpływ miała nie tylko zmiana upodobań kulinarnych Rzymian przejawiająca się w upodobaniu do serwowania na ucztach wyszukanych potraw i egzotycznych gatunków zwierząt i ryb, ale przede wszystkim popularność publicznych i prywatnych spektakli i parad (venationes i spectacula) organizowanych przy okazji świąt, festynów i triumfów, w trakcie których prezentowano pokazy różnych gatunków fauny, walki z dzikimi zwierzętami, i którym towarzyszyły wystawne uczty i bankiety oraz, mająca hellenistyczne korzenie, moda na polowanie jako sposób spędzania wolnego czasu przez rzymskiego arystokratę. Na temat rzymskich spectacula i venationes z udziałem dzikich zwierząt por. R.J. Lane Fox, Ancient Hunting: from Homer to Polybios, [w:] Human Landscapes in Classical Antiquity. Environment and Culture, red. J. Salmon, G. Shipley, New York 1996, s. 128-153; D. SŁAPEK, Gladiatorzy i polityka. Igrzyska w okresie późnej Republiki Rzymskiej, Wrocław 1995; IDEM, Sport $i$ widowiska w świecie antycznym. Kompendium, Kraków-Warszawa 2010, s. 703-711; C. Epplett, Animal 'spectacula' of the Roman Empire, Columbia 2001; IDEM, The preparation of animals for Roman 'spectacula': 'vivaria' and their administration, «Ludica» 9/2003, s. 76-92; IDEM, Roman Beast Hunts, [w:] P. Christesen, D.G. Kyle, A Companion to Sport and Spectacle in Greek and Roman Antiquity, Chichester 2014, s. 505-519. M. MacKinnon, Supplying Exotic Animals for the Roman Amphitheatre Games. New Reconstructions combining Archeological, Ancient Textual, Historical and Etnographic Data, «Mouseion» 3.6/2006, s. 137-161; C. Lo Giudice, L’impiego degli animali negli spettacoli romani: 'venatio' e 'damnatio ad bestias', «Italies. Revue d'ètudes italiennes» 12/2008, s. 361-395. Na temat stosunku Rzymian i rzymskich elit do polowania por. J. AYMARD, La chasse romaine. Essai sur les chasses romaines des origines à la fin du siècle des Antonins (Cynegetica), Paris 1951; J.K. Anderson, Hunting in the Ancient World, Berkeley-Los Angeles-London 1985, s. 83-85; C.M.C. Green, Did the Romans hunt?, "Classical Antiquity» 15.2/1996, s. 222-260; P. GAlloni, Storia e cultura della caccia. Dalla preistoria a oggi, Roma 2000, s. 71-72; A.D. Manfredini, „Chi caccia e chi è cacciato”..., s. 7-46; N.B. Crowther, Sport in Ancient Times, Westport 2007, s. 87-88, 113-11; M. JALlet-HuAnt, La chasse dans l'Antiquité romaine, Montbel 2008; Chasses antiques. Pratiques et représentations dans le monde gréco-romain (IIIe s. av.-IVe s. apr. J.-C.), [w:] Actes du colloque international de Rennes (Université Rennes II, 20-21 septembre 2007), (Archéologie et Culture), red. J. Trinquier, Ch. Vendries, Rennes 2009; D. SŁapek, Sport i widowiska..., s. 450-453, 703-708; C. Epplett, Roman Beast Hunts..., s. 505-519; E. RaGA, Réflexions sur le 
nych zysków, co skłania rzymskich nobiles do zakładania ich hodowli w zorganizowanych vivaria ${ }^{6}$. Obok tradycyjnych rezerwatów, w których zwierzęta były hodowane na zamkniętej przestrzeni pod bezpośrednią kontrolą właściciela hodowli, popularne staje się również otaczanie murem całych połaci lasu i tworzenie sui generis parków myśliwskich, w których różne gatunki dzikich zwierząt i ptactwa żyły w swoim środowisku naturalnym? ${ }^{7}$.

Dochodowość vivaria i rezerwatów dzikiej zwierzyny, które stały się pełnoprawnym źródłem zysków pozyskiwanych z terenów villa, podobnie jak wcześniej dochody z uprawy ziemi i hodowli zwierząt domowych, zrodziła z jednej strony potrzebę zagwarantowania właścicielom vivaria wyłączności na polowanie i czerpanie dochodów ze zwierząt pochodzących z takich hodowli, z drugiej uwzględnienia tego typu dochodów w kategorii korzyści, które przynosił fundus. Rzymscy iurisprudentes, wychodząc naprzeciw tym potrzebom, uznają zatem dzikie zwierzęta znajdujące się w vivaria i ryby trzymane w sztucznych zbiornikach wodnych za należące do właściciela takiej hodowli, co w konsekwencji uniemożliwiało osobom trzecim polowanie na nie i nabywanie ich własności ${ }^{8}$. Kolejną konsekwencją docenienia znaczenia ekonomicznego

rapport ville/campagne dans l'Antiquité tardive au travers de quelques discours sur la chasse, «Revue belge de philologie et d'histoire» 89.2/2011, s. 659-668; M. MACKinnon, Hunting in Roman Antiquity, [w:] The Oxford Handbook of Animals in Classical Thought and Life, red. G. LindsAy CAMPBELL, Oxford 2014, s. 207-213.

${ }^{6}$ W dziele Warrona (Varro, De re rust. 3,3,6) zwierzęce rezerwaty z I w. p.n.e. są wyraźnie przeciwstawiane dawnym hodowlom związanym z frugalitas przodków, służącym przede wszystkim zaspokojeniu podstawowych potrzeb rzymskiej familia oraz dostarczającym pater familias rozrywki z polowania. Por. N. Morley, Frugality and Roman economic thinking in Varro's Rerum rusticarum, "I quaderni del Ramo d'Oro on line» 10/2018, s. 41-54. Takie hodowle zakładane były przede wszystkim dla zysku, ale służyły również delectatio, dostarczając przyjemności płynącej z obcowania $\mathrm{z}$ naturą i stanowiąc ostentacyjną manifestację posiadanego bogactwa (Varro, De re rust. 3,3,5).

$7 \quad$ Plin., Nat. hist. 8,211; Varro, De re rust. 3,3,8; Colum., De re rust. 9,1,6.

8 W ten sposób, formalnie nie negując zasady, że dzikie zwierzęta żyjące w stanie natury nie należą do nikogo i podlegają zawłaszczeniu, juryści rzymscy doprowadzili do znacznego jej ograniczenia, de facto uniemożliwiając osobom trzecim polowanie na zwierzynę i ptactwo oraz łowienie ryb znajdujących się w zorganizowanych 
hodowli dzikich zwierząt było zaś rozszerzenie tradycyjnej koncepcji fructus fundi na zwierzęta hodowane $\mathrm{w}$ vivaria oraz dochody pozyskiwane $z$ ich sprzedaży i wynajmu, a także uznanie personelu i narzędzi służących do polowania za instrumentum fund $i^{9}$.

Przedmiotem analizy w niniejszym artykule będą zatem teksty, w których juryści traktują upolowaną zwierzynę, schwytane ptactwo czy ryby albo dochody pozyskiwane z polowania i połowu jako fructus oraz odwołują się do koncepcji pożytku jako tytułu nabycia własności dzikich zwierząt. Artykuł ten stanowi kontynuację badań prowadzonych przeze mnie wcześniej, których wyniki zostały opublikowane w artykułach: 'Accessio ab alluvione' $i$ 'reditus venationis et aucupii' jako 'fructus fundi'. Kilka uwag na marginesie PS. 3,6,22 ${ }^{10}$ oraz Polowanie na dzikie zwierzęta jako jeden ze sposobów wykonywania stużebności użytkowania $w$ prawie rzymskim ${ }^{11} \mathrm{i}$ jest próbą reinterpretacji omawianych $\mathrm{w}$ nich tekstów, przede wszystkim zaś tekstu D. 7,1,9,5 oraz tekstu D. 7,1,62 pr., dotyczących potraktowania dzikiej zwierzyny oraz dochodów pozyskiwanych z jej sprzedaży jako korzyści regularnie i systematycznie prokurowanej przez fundus. Zestawienie ze sobą tych dwóch tekstów pozwala bowiem w moim przekonaniu na zaproponowanie alternatywnej do przedstawionej w wcześniejszych opracowaniach ich interpretacji w kontekście ewidentnego od końca republiki kontrastu między zasadą wolności polowania na omnia quae terra mari caelo capiuntur a potrzebą

hodowlach i rezerwatach dzikiej zwierzyny. Szerzej na ten temat statusu prawnego zwierząt żyjących w vivaria i rezerwatach: Z. BENINCASA, 'Si vivariis inclusae ferae' ... Status prawny dzikich zwierząt żyjących w 'vivaria' i parkach myśliwskich $w$ prawie rzymskim, «Zeszyty Prawnicze»13.4/2013, s. 5-41; EADEM, Alcune riflessioni..., s. 39-62.

9 Por. D. 33,7,12,12-13; D. 33,7,22 pr. PS 3,6,41; 3,6,45. Na temat instrumentum venationis por. G. LOMBARDI, op. cit., s. 277-290; G. Polara, op. cit., s. 211-222; R. CARDIlli, op. cit., s. 351; A.M. Giomaro, Dall'instruere' all'instrumentum' e viceversa nell'economia della Roma antica, «Studi Urbinati» 62.1-2/2011, s. 135-136, 145-146; A.D. MANFREDINI, "Chi caccia e chi è cacciato"..., s. 37-40.

10 Z. Benincasa, 'Accessio ab alluvione' i 'reditus venationis et aucupii' jako 'fructus fundi'. Kilka uwag na marginesie PS. 3,6,22, «Zeszyty Prawnicze» 15.2/2015, s. 135-159.

${ }_{11}$ Z. Benincasa, Polowanie na dzikie zwierzęta jako jeden ze sposobów wykonywania stużebności użytkowania w prawie rzymskim, «Studia i Materiały Ośrodka Kultury Leśnej» 15/2016, s. 9-29. 
zapewnienia ochrony ze strony prawa osobom, które chciały czerpać zyski z hodowli i polowania na dziką zwierzynę, ptactwo i ryby.

Jednym z najwcześniejszych tekstów dotyczących możliwości uznania za pożytek z gruntu dzikich zwierząt jest tekst Iulianusa, prawdopodobnie relacjonujący poglądy jednego z uczniów Sabinusa ${ }^{12}$, w którym nie uznaje się dzikich zwierząt żyjących w stanie natury za pożytek z gruntu, $\mathrm{z}$ wyjątkiem sytuacji, w której fructus fundi ex venatione constat, a więc korzyści, jakie przynosi grunt, stanowi upolowana zwierzyna ${ }^{13}$.

D. 22,1,26 (Iul. 6 ex Minic.): Venationem fructu[s]m fundi negavit esse, nisi fructus fundi ex venatione constat. [Iulianus w księdze szóstej Odpowiedzi prawnych Miniciusa: Stwierdził, że zdobycz myśliwska nie stanowi pożytku z gruntu, chyba że myślistwo jest jedyną formą czerpania pożytków z [danego] gruntu] ${ }^{14}$.

Większość autorów za grunt, w odniesieniu do którego pożytek z gruntu stanowi upolowana zwierzyna (venatio) ${ }^{15}$, uznaje teren, na którym znajdowały się zorganizowane hodowle dzikich zwierząt ( $v i$ varia) albo rozległe rezerwaty myśliwskie ${ }^{16}$. Interpretacja ta wydaje się

12 Przyjmuje się, że reguła pochodzi od Miniciusa, ucznia Sabinusa, który prawdopodobnie powoływał się na poglądy swojego mistrza. Por. R. CARdilli, op. cit., s. 217; A.D. Manfredini, „Chi caccia e chi è cacciato”..., s. 38.

13 Sceptyczne stanowisko wobec autentycznego charakteru tego tekstu zajęli G. Lombardi, op. cit., s. 294-298, i G. Polara, op. cit., s. 22, przyp. 17, s. 246-247. Za autentyczny uznaje tekst natomiast R. CARDILLI, op. cit., s. 217-218. Uznanie, że dzikie zwierzęta żyjące na gruncie w stanie naturalis libertas i stanowiące część natury nie stanowią fructus fundi, stanowiło logiczną konsekwencję uznania za fructus jedynie korzyści pozyskiwanych bezpośrednio i regularnie z gruntu jako rzeczy macierzystej.

14 'Digesta Iustiniani'. Digesta Justyniańskie. Tekst i przekład, IV, red. T. PALMIRsKI, Kraków 2014, s. 169.

15 Na temat interpretacji terminów venatio i aucupium por. G. Polara, op. cit., s. 69-70; R. MARTini, op. cit., s. 216-217; R. CARdilli, op. cit., s. 204.

16 Jak utrzymuje Polara, za grunt, z którego dochód polegał na venatio, mógł być uznany wyłącznie grunt, którego właściciel zorganizował na nim vivaria lub rozległy rezerwat dzikiej zwierzyny. Autor ten wyklucza zatem możliwość potraktowania jako fructus fundi dochodów pochodzących z polowania na dziką zwierzynę pozostającą w stanie naturalis libertas. Stoi on jednak na stanowisku, że nie było różnicy między statusem prawnym zwierząt hodowanych w vivaria a tych, żyjących na wydzielonej 
niewątpliwie słuszna w odniesieniu do tradycyjnych vivaria, w których na zamkniętej przestrzeni właściciel gruntu hodował różne gatunki dzikich zwierząt, ptactwa i ryb, jednak możliwość potraktowania jako fructus fundi dzikich zwierząt żyjących w swoim środowisku naturalnym w zagrodzonym przez właściciela nieruchomości rezerwacie nie jest moim zdaniem oczywista i być może nie była oczywista również dla jurystów rzymskich. Jak wynika bowiem z tekstu dotyczącego zagadnienia posiadania dzikich zwierząt żyjących w warunkach naturalnych na wydzielonym przez właściciela obszarze, sam fakt wydzielenia zamkniętej przestrzeni, w której przebywały takie zwierzęta, nie może być zdaniem Paulusa równoznaczny $z$ automatycznym nabyciem posiadania, a więc zarazem i własności takich zwierząt. Co prawda, sam fakt, że Paulus analizuje taką ewentualność, może sugerować, iż niektórzy juryści byli skłonni uznać sam akt ogrodzenia terenu za równoznaczny z zawłaszczeniem żyjących na tym terenie dzikich zwierząt, jednak jurysta ten wyraźnie wykazuje, że taka koncepcja prowadzi do absurdalnej jego zdaniem konstatacji, iż nabywca ogrodzonego lasu staje się jednocześnie posiadaczem wszystkich dzikich zwierząt żyjących w takim lesie ${ }^{17}$.

przestrzeni w rozległych rezerwatach (te ostatnie przeciwstawia ferae quae in silvis circumseptis vagantur, o których wspomina Paulus w tekście D. 41,2,3,14). Ten ostatni pogląd jednak nie wydaje się znajdować potwierdzenia w źródłach i wiąże się z koniecznością uznania niektórych źródeł za interpolowane. Por. G. Polara, op. cit., s. 102-105, 121-125, 134-135, 233-244, i uwagi krytyczne pod adresem koncepcji tego autora: R. MArtini, op. cit., s. 217; Z. Benincasa, 'Si vivariis inclusae ferae'..., s. 19-24. Podobnie A.D. Manfredini („Chi caccia e chi è cacciato”..., s. 39) uważa, że teksty, które dotyczą dzikiej zwierzyny jako pożytku z gruntu, odnoszą się do gruntów, na których zorganizowano vivaria lub rozległe rezerwaty i które były wykorzystywane wyłącznie do celów myśliwskich i łowieckich.

17 D. 41,2,3,14 (Paul. 54 ad ed.): Item feras bestias, quas vivariis incluserimus, et pisces, quos in piscinas coiecerimus a nobis possideri. sed eos pisces, qui in stagno sint aut feras, quae in silvis circumseptis vagantur, a nobis non possideri, quoniam relictae sint in libertate naturali: alioquin etiam si quis silvam emerit, videri eum omnes feras possidere, quod falsum est. W cytowanym tekście komentarza do edyktu Paulus przeciwstawia status prawny dzikich zwierząt zamkniętych na obszarze wydzielonym przez właściciela gruntu (vivarium, piscina) położeniu zwierząt, które żyły w swoim środowisku naturalnym w zbiorniku wodnym albo w ogrodzonym lesie (in stagno albo in silvis circumseptis). Za będące w posiadaniu właściciela gruntu, a więc stanowiące jego 
Nie można wykluczyć, że w odniesieniu do takich rozległych rezerwatów dzikiej zwierzyny, juryści rzymscy w celu zagwarantowania właścicielom takich rezerwatów wyłączności na polowanie na znajdującą się na jego obszarze dziką zwierzynę wykorzystali inną koncepcję, mającą zastosowanie do zwierząt określanych przez jurystów jako stworzenia, które z nawyku zwykły oddalać się i powracać (quae ex consuetudine abire et redire solent). Pozwalała ona uznać, że dzikie zwierzę nieznajdujące się pod bezpośrednią kontrolą jego hodowcy pozostawało jego własnością tak długo, jak długo zachowywało nawyk okresowego powracania do niego (animus revertendi) ${ }^{18}$. Koncepcja ta prawdopodobnie oryginalnie została stworzona na potrzeby hodowa-

własność, Paulus uznał tylko te zwierzęta, które zostały umieszczone przez właściciela w zorganizowanej przez niego hodowli, dzięki czemu miał możliwość ich kontroli, co było równoznaczne z odebraniem tym zwierzętom libertas naturalis, a więc ich zawłaszczeniem. Natomiast dzikie zwierzęta żyjące w ich naturalnym środowisku, in stagno albo in silvis circumseptis, nadal uważał on za relictae in libertate naturali, a więc nienależące do nikogo. Aby uzasadnić takie rozstrzygnięcie, Paulus wskazuje, że uznanie zwierząt żyjących w stanie natury na zagrodzonym obszarze leśnym za będące w posiadaniu właściciela tegoż lasu implikuje uznanie, że właściciel, sprzedając ogrodzony las, sprzedaje również wszystkie dzikie zwierzęta w nim żyjące, co należy uznać za pogląd oczywiście fałszywy (quod falsum est). Por. Z. Benincasa, 'Si vivariis inclusae ferae'..., s. 16-18.

18 G. 2,68; D. 41,1,5,5; I. 2,1,15. Na temat prawa własności pszczół i innych zwierząt quae ex consuetudine abire et redire solent, B.W. FrIER, Bees and Lawyers, "Classical Journal» 78.2/1982-1983, s. 105-114; D. DAube, Doves and Bees, [w:] Droits de L'antiquité et sociologie juridique. Mélanges Henri Lévy-Bruhl, Paris 1959, s. 64-65; G. Polara, Le 'venationes'..., s. 132-153; H. Hausmaninger, Celsus gegen Proculus, [w:] Festschrift Ulrich von Lübtow, Rheinfelsen 1991, s. 53-62; B.W. FrIER, Why did the Jurists change Roman Law? Bees and Lawyers revisited, "Index» 22/1994, s. 135-137, 139-141; D. MAntovanI, I giuristi, il retore e le api. 'Ius controversum' e 'natura' nella 'Declamatio Maior XIII', [w:] Testi e problemi del giusnaturalismo romano, red. D. Mantovani, A. Schiavone, Pavia 2007, s. 323-385; M. PolOJAC, op. cit., s. 740-742; P. NiCZY PORUK, Rzymskie regulacje pierwowzorem wspótczesnych rozwiazań prawnych wakresie pszczelarstwa i bartnictwa, [w:] Prawne aspekty prowadzenia działalności bartnej. Wybrane zagadnienia, red. E.K. CzECH, Białystok 2015, s. 17-35; Z. BeNINCASA, „Co się tyczy stworzeń, które z nawyku zwykly oddalać się i powracać ...." - koncepcja animus revertendi a wolność polowania na dzikie zwierzęta w prawie rzymskim, «Studia i Materiały Ośrodka Kultury Leśnej» 18/2019, s. 33-52. 
nych w przydomowych hodowlach pszczół i gołębi, by w końcu republiki znaleźć swoje analogiczne zastosowanie do innych gatunków zwierząt, w tym pawi i jeleni, trzymanych dla zysku w rozległych rezerwatach i regularnie dokarmianych na umówiony sygnał w określonym miejscu przez właściciela hodowli. Dzięki tej rozszerzającej interpretacji możliwe stało się do pewnego stopnia zrównanie statusu zwierząt żyjących w zorganizowanych hodowlach i tych quae in silvis circumseptis vagantur, co pozwoliło na znaczne ograniczenie zasady, że dzikie zwierzęta bytujące w stanie naturalis libertas stanowią res nullius i mogą być zawłaszczone przez każdego ${ }^{19}$.

Zagadnienie potraktowania jako pożytek gruntu zysków z polowania na dzikie zwierzęta i ptactwo oraz łowienia ryb (reditus venationum, aucupiorum et piscationum) na gruncie oddanym w usufructus stanowi przedmiot rozważań Ulpiana w siedemnastej księdze komentarza ad Sabinum, w której jurysta ten przeprowadza dłuższy wywód na temat prawa użytkownika do określonych korzyści o charakterze okazjonalnym i incydentalnym, niepochodzących bezpośrednio z użytkowanego

19 Regula, o której wspomina Gaius, miała zastosowanie do bardzo różnych gatunków zwierząt. Z jednej strony dotyczyła takich zwierząt, jak pszczoły albo gołębie, które $z$ uwagi na swoją naturę i instynktowne zachowanie gatunkowe musiały mieć swobodę oddalania się od gniazda, by potem powrócić. Ich hodowca musiał zatem umożliwić im wylatywanie z ula czy gołębnika i oddalanie się na duże odległości, tracąc tym samym możliwość sprawowania nad nimi bezpośredniej kontroli. Ingerencja człowieka w naturalny tryb życia tych zwierząt ograniczała się jedynie do kontrolowania i stymulowania ich naturalnego animus revertendi, np. poprzez stworzenie optymalnych warunków w gołębniku czy ulu i zapobieżenie ucieczce roju. Z drugiej jednak strony ta sama reguła znajdowała swoje zastosowanie do zwierząt takich jak pawie i jelenie, których animus revertendi nie był wynikiem ich zachowania instynktownego, ale był rezultatem oddziaływania człowieka na naturę zwierzęcia dzikiego w procesie oswajania prowadzącym do wyrobieniu w zwierzęciu nawyku powracania do określonego miejsca, w którym otrzymywało ono pożywienie. Znamienne w tym kontekście są teksty Warrona i Kolumelli, które potwierdzają praktykę dokarmiania dzikich zwierząt, m.in. dzików i jeleni, przez właścicieli rozległych rezerwatów myśliwskich (por. Colum., De re rustica 9,1,6; Varro, De rer. rust., 3,13,1-2). Szerzej na ten temat por. Z. BEninCAsA, Alcune riflessioni sulla libertà di caccia..., s. 39-62; Z. BENINCASA, „Co się tyczy stworzeń, które z nawyku zwykły oddalać się i powracać”..., s. 33-52. 
gruntu, ale będących wynikiem działania sił natury lub procesów naturalnych (D. 7,1,9,5 pr.-5).

Wywód ten otwiera słynny passus, w którym jurysta seweriański stwierdza, że wszystko to, co rodzi się na gruncie, cokolwiek może być z tego gruntu pozyskane, zalicza się do kategorii pożytków z gruntu, pod warunkiem iż użytkowanie jest wykonywane zgodnie z kryterium arbitrium boni viri ${ }^{20}$ :

D. 7,1,9 pr. (Ulp. 17 ad Sab.): Item si fundi usus fructus sit legatus, quidquid in fundo nascitur, quidquid inde percipi potest, ipsius fructus est, sic tamen ut boni viri arbitratu fruatur. nam et Celsus libro octavo decimo digestorum scribit cogi eum posse recte colere. [Ulpianus w księdze siedemnastej Komentarza do pism Sabinusa: Tak samo, jeśli użytkowanie posiadłości wiejskiej zostało zapisane w testamencie, cokolwiek rodzi się na gruncie, cokolwiek z niego może być zabrane, zalicza się do pożytków, które ów grunt przynosi, pod warunkiem jednak wykonywania służebności w sposób uczciwy. Celsus w księdze osiemnastej Digestów pisze bowiem także, że użytkownik może być zmuszony do należytego uprawiania gruntu $]^{21}$.

Dalsza część komentarza Ulpiana poświęcona jest analizie konkretnych przypadków, które mogły budzić kontrowersje w zakresie możliwości korzystania przez użytkownika z takich korzyści, których bezpośrednim źródłem nie był fundus, ale pochodziły one z natury bądź były wynikiem działania sił naturalnych. Pierwszy rozważany kazus dotyczy prawa użytkownika do roju dzikich pszczół osiadłego na gruncie oddanym w ususfructus.

D. 7,1,9,1 (Ulp. 17 ad Sab.): Et si apes in eo fundo sint, earum quoque usus fructus ad eum pertinet. [Ulpianus w księdze siedemnastej Komentarza do pism Sabinusa: I jeśli na terenie posiadłości

20 Na temat interpretacji tego tekstu por. przede wszystkim R. CARDILLI, op. cit., s. 194-197, 212-213.

${ }_{21}^{21}$ 'Digesta Iustiniani’. Digesta Justyniańskie. Tekst i przekład, II, Kraków, s. 151. 
znajdują się pszczoły, [zapisobierca] ma również prawo do ich użytkowania] ${ }^{22}$.

Pszczoły, które nie były hodowane przez właściciela gruntu w zorganizowanej hodowli, podobnie jak inne dzikie zwierzęta żyjące w stanie naturalis libertas, były uważane za rzecz niczyją podlegającą zawłaszczeniu $^{23}$. Użytkownik miał jednak zdaniem Ulpiana prawo do czerpania z nich korzyści w ramach przysługującej mu służebności, chociaż obecność roju dzikich pszczół na gruncie oddanym w użytkowanie mogła być zdarzeniem okazjonalnym i incydentalnym.

Kolejny przypadek rozważany przez Ulpiana to grunt, na którym znajdowały się kamieniołomy, kopalnie kredy czy piasku.

D. 7,1,9,2 (Ulp. 17 ad Sab.): Sed si lapidicinas habeat et lapidem caedere velit vel cretifodinas habeat vel harenas, omnibus his usurum Sabinus ait quasi bonum patrem familias: quam sententiam puto veram. [Ulpianus w księdze siedemnastej Komentarza do pism Sabinusa: Lecz jeśli znajduje się tam kamieniołom, a użytkownik chciałby tłuc kamienie, lub jeśli znajduje się tam wyrobisko kredy albo piasek, Sabinus stwierdza, że może on wszystkiego tego używać przy zachowaniu staranności przynależnej ojcu rodziny. Ten pogląd uważam za słuszny] ${ }^{24}$.

W tym przypadku Ulpian również opowiada się za prawem użytkownika do czerpania korzyści ekonomicznych z tych zasobów. Zastrzega jednak, powołując się na poglądy Sabinusa, że ich eksploatacja powinna być wykonywana przy zachowaniu staranności bonus pater familias, a więc w granicach wyznaczonych przez potrzeby użytkowanego gruntu ${ }^{25}$.

22 Ibidem.

23 D. 47,2,26 pr.; D. 41,1,5,2. Por. Z. BenincasA, 'Si vivariis inclusae ferae'..., s. 18-19.

24 'Digesta Iustiniani'. Digesta Justyniańskie..., II, s. 151-153.

25 Na temat możliwości czerpania przez użytkownika korzyści z kopalni minerałów znajdujących się na gruncie oddanym w ususfructus por. G. Grosso, Usufrutto e figure affini nel diritto romano, Torino 1958, s. 114-119, 176-178; G. NeGRI, Diritto minerario romano, I, Milano 1985, s. 193 i n., 286-287; R. LAMbertini, 'Lapis crescere potest'. I frutti del regno minerale, "Archivio Giuridico» 204/1994, s. 97-165; R. CARDILLI, op. cit., s. 293-295. 
W kolejnym tekście Ulpian zastanawia się, czy analogiczne prawo do eksploatacji złóż mineralnych przysługiwałoby użytkownikowi w sytuacji, w której zostałyby one odkryte na gruncie post usum fructum legatum sint, a więc dopiero po ustanowieniu ususfructus ${ }^{26}$.

D. 7,1,9,3 (Ulp. 17 ad Sab.): Sed et si haec metalla post usum fructum legatum sint inventa, cum totius agri relinquatur usus fructus, non partium, continentur legato. [Ulpianus w księdze siedemnastej Komentarza do pism Sabinusa: Lecz również jeżeli owe złoża zostały znalezione po ustanowieniu użytkowania w drodze zapisu, stają się one jego przedmiotem, o ile pozostawiono użytkowanie całego gruntu, a nie jego części] ${ }^{27}$.

Zdaniem tego jurysty, jeżeli zapisem objęty był cały grunt, a nie tylko jego część, użytkownik miał prawo korzystania z minerałów odkrytych na gruncie, nawet jeżeli ich odkrycie było dokonane już po ustanowieniu służebności użytkowania i złoża te nie były wcześniej eksploatowane przez właściciela ${ }^{28}$.

Kolejny przypadek, który Ulpian uznaje za analogiczny do wcześniejszego kazusu, a więc odkrycia na użytkowanym gruncie złóż minerałów, które nastąpiło już po ustanowieniu służebności użytkowania, to kazus powiększenia gruntu, które nastąpiło wskutek działania prądów rzecznych ${ }^{29}$.

26 Por. R. CARdilli, op. cit., s. 294-295.

27 'Digesta Iustiniani'. Digesta Justyniańskie..., II, s. 153.

28 Na temat interpretacji tego tekstu por. przede wszystkim R. CARDILLI, op. cit., s. 294-295.

29 Na temat alluvio zob. M. SARGENTI, Tre osservazioni sul regime degli incrementifluviali, «SDHI» 23/1957, s. 352-357; P. MADDALENA, Gli incrementifluviali nella visione giurisprudenziale classica, Napoli1970, s. 4-37; L. MagAnZANI, Gli incrementifluviali in Fiorentino VI inst. (D. 41.1.16), «SDHI» 59/1993, s. 207-258; EADEM, I fenomeni fluviali e la situazione giuridica del suolo rivierasco: tracce di un dibattito giurisprudenziale, «Ius» 44/1997, s. 343-390; A. BARra, Gli incrementi fluviali in diritto romano, «Paesi e uomini nel tempo. Collane di monografie di storia, scienze ed arti»10/1998; K. KAŃsKA, R. MAŃKo, 'Alluvio' i 'mutatio alvei'. Zastosowanie regut rzymskich $w$ prawie międzynarodowym publicznym, «Studia Iuridica» 41/2003, s. 136-140; R. Św IRGoŃ-SKoK, Nieruchomość i zasady akcesji według prawa rzymskiego, Rzeszów 2007, s. 79-92; M.P. PAVESE, 'Fundus cum vadis et alluvionibus'. Gli incrementi fluviali fra documenti della prassi e riflessione 
D. 7,1,9,4 (Ulp. 17 ad Sab.): Huic vicinus tractatus est, qui solet in eo quod accessit tractari: et placuit alluvionis quoque usum fructum ad fructuarium pertinere. sed si insula iuxta fundum in flumine nata sit, eius usum fructum ad fructuarium non pertinere Pegasus scribit, licet proprietati accedat: esse enim veluti proprium fundum, cuius usus fructus ad te non pertineat. quae sententia non est sine ratione: nam ubi latitet incrementum, et usus fructus augetur, ubi autem apparet separatum, fructuario non accedit. [Ulpianus w księdze siedemnastej Komentarza do pism Sabinusa: Podobny do wspomnianej wyżej kwestii jest przypadek związany z połączeniem się dwóch rzeczy. I przyjął się pogląd, że prawo do użytkowania przymuliska (gruntu powstałego $\mathrm{z}$ osadu naniesionego przez rzekę) należy do użytkownika [gruntu przybrzeżnego]. Jeśli jednak na rzece powstała wyspa, prawo do jej użytkowania, jak pisze Pegasus, nie należy do użytkownika [gruntu przybrzeżnego], chociaż staje się ona własnością właściciela tegoż gruntu. Jest ona bowiem jakby odrębnym gruntem i prawo do jego użytkowania nie należy do ciebie. Ta opinia nie jest pozbawiona podstaw. Kiedy bowiem powiększenie gruntu [wskutek powolnego nanoszenia osadu przez rzekę] powstaje w sposób niezauważalny, powiększa się też użytkowanie, kiedy natomiast [nowa rzecz] pojawia się jako coś odrębnego [od użytkowanego przedmiotu, wówczas] nie przypada ona użytkownikowi $]^{30}$.

W pierwszej części cytowanego tekstu Ulpian wskazuje na analogię między odkryciem przez użytkownika złóż minerałów na użytkowanym gruncie już po ustanowieniu służebności a powiększeniem gruntu wskutek naturalnego zjawiska alluvio. Uznaje on, że powiększenie nieruchomości wskutek powolnego i systematycznego nanoszenia przez rzekę osadu, które nastąpiło już po ustanowieniu na gruncie służebności użytkowania, powoduje, iż służebność ususfructus rozciąga się również

giurisprudenziale romana, Roma 2004; P. CAstillo Pascual, Die Kontroverse 'De alluvione’ bei Gromatikern und Juristen, «eTopoi. Journal for Ancient Studies» 2/20122013, s. 1-23, w szczególności s. 10-11.

30 'Digesta Iustiniani'. Digesta Justyniańskie..., II, s. 153. 
na przyłączony do nieruchomości obszar, o ile służebność została ustanowiona na całym gruncie, a nie na jego części ${ }^{31}$.

Po omówieniu kazusu alluvio oraz insula in flumine nata, Ulpian przechodzi do analizy zagadnienia zysku pochodzącego z polowania na dzikie zwierzęta, ptactwo i połowu ryb, odwołując się do opinii jurysty republikańskiego Cassiusa, którego zdaniem aucupiorum, venationum et piscationum reditus ${ }^{32}$ przypadał użytkownikowi ${ }^{33}$.

D. 7,1,9,5 (Ulp. 17 ad Sab.): Aucupiorum quoque et venationum reditum Cassius ait libro octavo iuris civilis ad fructuarium pertinere: ergo et piscationum. [Ulpianus w księdze siedemnastej Komentarza do pism Sabinusa: Dochody płynące z polowania na ptaki i zwierzynę, jak stwierdza Cassius w księdze ósmej Prawa cywilnego,

31 W dalszej części omawianego tekstu Ulpian przeciwstawia kazusowi alluvio przypadek powstania wyspy na rzece w bezpośredniej bliskości użytkowanej nieruchomości. W tym miejscu odwołuje się do opinii jurysty z końca I w. n.e. Pegasusa, który, choć uznawał, że własność takiej wyspy przypadała właścicielowi gruntu, przy którego brzegu powstała, to jednak odmawiał użytkownikowi gruntu przybrzeżnego prawa do jej użytkowania, traktując ją jako grunt w pewnym sensie odrębny od nieruchomości, na której zostało ustanowione użytkowanie, którego nie dotyczy ustanowione wcześniej prawo do uti frui (esse enim veluti proprium fundum, cuius usus fructus ad te non pertineat). Ulpian co do zasady uznał za słuszną argumentację Pegasusa i w dalszej części tekstu wyjaśnił, że należy odróżnić przypadek, w którym powiększenie gruntu jest wynikiem powolnego nanoszenia przez rzekę osadu, który to proces następuje w sposób systematyczny i niezauważalny od przypadku, w którym wyspa utworzona przez nurt rzeczny pojawia się jako odrębna rzecz, teren oddzielony od nieruchomości nadbrzeżnej. W tym ostatnim przypadku, chociaż uznaje się właściciela nieruchomości nadbrzeżnej za właściciela wyspy powstałej w sąsiedztwie jego nieruchomości, nie uznaje się prawa użytkownika do korzystania z niej, bowiem prawo użytkowania nie powiększa swoich granic, co następuje jednak w przypadku powiększenia gruntu per alluvionem. Por. A. Metro, Un'ipotesi sul regime giuridico dell' insula in flumine nata', "Iura» 51/2000, s. 47-53.

32 Na temat znaczenia terminu reditus por. R. CARDILl, op. cit., s. 205, przyp. 43.

33 Por. również tekst D. 41,10,2, w którym mowa jest o nabyciu własności omnia quae terra mari caelo capiuntur i powiększeniu gruntu alluvione fluminum, oraz tekst PS 3,6,22, w którym rozważa się kazusy accessio ab alluvione oraz venationis et aucupii reditus. Na temat tych dwóch tekstów por. Z. Benincasa, 'Accessio ab alluvione'..., s. 135-159. 
przysługują użytkownikowi [gruntu]. Tym samym także te związane $\mathrm{z}$ połowem $\mathrm{ryb}]^{34}$.

Zgodnie z interpretacją tego tekstu, którą zaproponował Riccardo Cardilli, Cassius w ósmej księdze iuris civilis rozważał kazus gruntu nieprzeznaczonego do celów łowieckich, na którym w stanie natury bytowały różne gatunki dzikich zwierząt, ptaków i ryb, zastanawiając się, czy użytkownik ma prawo wynajmować osobom trzecim możliwość polowania na zwierzynę czy łowienia ryb na tym gruncie oraz zawierać kontrakty typu emptio spei w odniesieniu do schwytanej zwierzyny, ptaków i ryb. W tym kontekście Cardilli uznaje, że opinia Cassiusa, którego zdaniem aucupiorum et venationum et piscationum reditus przypada użytkownikowi, wskazuje na zerwanie z koncepcją fructus jako korzyści regularnie i systematycznie pozyskiwanej z gruntu na rzecz koncepcji pożytku obejmującej również korzyści natury ekonomicznej o charakterze okazjonalnym i niepewnym, jakie mogły stać się udziałem użytkownika z tytułu odpłatnego udostępnienia gruntu osobom trzecim. Autor ten sugeruje więc, że rozważane przez Cassiusa zagadnienie dotyczyło możliwości potraktowania jako fructus fundi zysków, jakie mógł okazjonalnie i incydentalnie pozyskiwać użytkownik z polowania na zwierzęta i ptactwo oraz łowienia ryb na gruncie oddanym w użytkowanie, który to grunt nie był przeznaczony do hodowli i polowania, a więc znajdujące się na nim w stanie natury dzikie zwierzęta, ptactwo i ryby nie stanowiły pożytku z gruntu ${ }^{35}$.

Interpretując opinię Cassiusa w szerszym kontekście przypadków analizowanych przez Ulpiana w siedemnastej księdze komentarza ad Sabinum w odniesieniu do ogólnej reguły quidquid in fundo nascitur, quidquid inde percipi potest, ipsius fructus est, można jednak zaproponować alternatywną interpretację zwrotu venationum, aucupiorum et piscationum reditus, nieograniczającą się tylko do przypadku okazjonalnych i incydentalnych zysków, jakie mogły stać się udziałem użytkownika z tytułu umożliwienia osobom trzecim polowania na dzikie zwierzęta, ptactwo oraz łowienia ryb na gruncie oddanym w użytkowanie. Starając

34 'Digesta Iustiniani'. Digesta Justyniańskie..., II, s. 152.

35 R. Cardilli, op. cit., s. 203-205. 
się bowiem odtworzyć „leitmotiv” wszystkich przypadków analizowanych przez Ulpiana w tej części komentarza ad Sabinum, a następnie umieszczonych przez kompilatorów we fragmencie D. 7,1,9,5 pr.-5, można zauważyć, że jurysta podejmował zagadnienie rozszerzenia prawa użytkowania na potencjalne korzyści, często o charakterze okazjonalnym i incydentalnym, które nie pochodziły bezpośrednio z gruntu oddanego w użytkowanie, ale z samej natury, ze szczególnym uwzględnieniem sytuacji, w których możliwość korzystania z nich pojawiła się już po ustanowieniu służebności. Zarówno pszczoły oraz inne zwierzęta żyjące w stanie natury na użytkowanym gruncie, jak i złoża minerałów odkryte na gruncie, a także powiększenie gruntu w wyniku fenomenu alluvio, nie były wytworem gruntu jako takiego, ale źródłem ich powstania była sama natura bądź działanie sił naturalnych. Można zatem utrzymywać, że miały charakter okazjonalny i incydentalny, co mogło rodzić wątpliwości dotyczące uprawnienia użytkownika do czerpania z nich korzyści w ramach przysługującego mu prawa do uti frui. W szczególności zaś kontrowersje mogła budzić sytuacja, w której ich pojawienie się czy odkrycie nastąpiło już po ustanowieniu służebności użytkowania: skoro wcześniej nie były one eksploatowane przez właściciela, powstawało pytanie, czy służebność, którą ten ostatni ustanowił, obejmowała prawo do korzystania również z takich korzyści. Jest bowiem znamienne, że Ulpian nie zastanawia się nad uznaniem za pożytek z gruntu samych dzikich pszczół czy zwierząt, ptaków i ryb żyjących w stanie naturalis libertas, czy terenu, o który per alluvionem powiększył się użytkowany grunt, czy wreszcie złóż minerałów, które zostały odkryte na użytkowanym gruncie, ale jedynie zastanawia się nad możliwością ich eksploatacji przez użytkownika w ramach przysługującej mu służebności. W rzeczywistości bowiem wszystkie te korzyści, jako pochodzące z natury (pszczoły, dzikie zwierzęta, złoża minerałów) bądź będące wynikiem działania procesów naturalnych (accessio ab alluvione), jako niepowiązane z samym gruntem, nie mogą być zaliczone do kategorii pożytków, jakie przynosi ten grunt w toku jego normalnej eksploatacji. Użytkownik miał jednak zdaniem Ulpiana prawo do korzystania z nich, bowiem służebność użytkowania obejmowała również prawo do korzystania z nowych możliwości eksploatacji gruntu, które pojawiły się już po 
ustanowieniu ususfructus, a dochód z ekonomicznej eksploatacji tych korzyści byłby potraktowany jako fructus fundi.

Przyjmując taką interpretację tekstu Ulpiana, termin aucupiorum et venationum et piscationum reditus oznaczałby każdy dochód, jaki mógłby stać się udziałem użytkownika z tytułu polowania, łowienia ryb czy chwytania ptactwa na użytkowanym gruncie, niezależnie od tego, czy byłby on pozyskiwany w sposób systematyczny i stały ze zorganizowanych na gruncie przez użytkownika vivaria, czy też nieregularnie albo okazjonalnie przez tegoż użytkownika z tytułu polowania i sprzedaży upolowanej zwierzyny. Intencją tego jurysty było bowiem pokazanie, że nawet jeżeli grunt oddany w użytkowanie nie był przez właściciela oryginalnie przeznaczony na cele pastio villatica, użytkownik miał prawo, wykorzystując naturalne warunki terenu, zaadaptować go do takiego użytku, organizując hodowle dzikich zwierząt, ptaków i ryb, mógł również, w sposób okazjonalny i niesystematyczny, czerpać zyski z polowania na dzikie zwierzęta, ptactwo oraz ryby. W tym pierwszym przypadku, w którym na gruncie oddanym w ususfructus użytkownik założyłby zorganizowane hodowle, zarówno dzika zwierzyna, ptactwo i ryby, jak i zyski z ich sprzedaży stanowiłyby pożytek, jaki przynosi grunt, w tym drugim przypadku zaś, sama dzika zwierzyna, ptactwo i ryby pozostające w stanie naturalis libertas nie mogłyby być uznane za pożytek z gruntu, jednak użytkownik mógłby sprzedawać upolowane zwierzęta i ptaki czy złowione ryby albo odpłatnie umożliwiać osobom trzecim polowanie czy połów na gruncie i korzyści, które z tego tytułu by uzyskał, stanowiłyby jego wyłączny dochód.

Za dowód na niejednoznaczny charakter polowania jako sposobu wykonywania służebności użytkowania i kontrowersyjność potraktowania dzikich zwierząt jako fructus fundi, w relacji do zasady wolności polowania na omnia quae terra mari caelo capiuntur, mogą być uznane także dwa teksty pochodzące z disputationes Tryphoninusa, w których rozważa się prawo użytkownika do polowania na gruncie oddanym w ususfructus oraz tytuł prawny nabycia przez niego własności schwytanej zwierzyny, a także sposób wykonywania służebności użytkowania 
w odniesieniu do gruntu, na którym znajdowało się vivarium (D. 7,1,62. pr.-1) ${ }^{36}$.

Szczególne problemy interpretacyjne stwarza tekst D. 7,1,62 pr., w którym Tryphoninus, uznając prawo użytkownika do polowania na gruncie oddanym w użytkowanie i nabywania własności upolowanych dzikich zwierząt, wskazuje, że własność upolowanej zwierzyny jest przez tego ostatniego nabywana fructus iure aut gentium, a więc albo jako pożytek z gruntu, albo przez zawłaszczenie.

D. 7,1,62 pr.-1 (Tryph. 7 disput.): Usufructuarium venari in saltibus vel montibus possessionis probe dicitur: nec aprum aut cervum quem ceperit proprium domini capit, sed aut fructus iure aut gentium suos facit ${ }^{37}$. [Tryphoninus w księdze siódmej Dysput: Słusznie uważa się, że użytkownik może polować w lasach i na wzgórzach znajdujących się na terenie posiadłości, którą użytkuje. Stąd dzika lub jelenia, którego upolował, nie bierze jako rzeczy należącej do właściciela [tejże posiadłości], lecz nabywa ich własność albo na podstawie [przysługującego użytkownikowi] prawa do pobierania pożytków, albo na podstawie ius gentium [wskutek zawłaszczenia rzeczy $]^{38}$.

Wątpliwości budzi nie tylko celowość rozważania przez tego jurystę zagadnienia, czy użytkownik może na gruncie oddanym w użytkowanie polować na dzikie zwierzęta (skoro prawo do polowania na zwierzynę

36 Na temat interpretacji tych tekstów por. Z. Benincasa, Polowanie na dzikie zwierzęta..., s. 9-29.

37 Powszechnie przyjęta jest korekta końcowej części tekstu zaproponowana przez Mommsena w Editio Maior, który rekonstruuje oryginalny tekst «sed fructus aut iure aut gentium suos facit» w sposób następujący: «sed aut fructus iure aut gentium». Por. G. Grosso, op. cit., s. 180. Odmienną rekonstrukcję przyjął we włoskiej edycji Digestów Scialoja, który uznał, że własność upolowanych na użytkowanym gruncie dzikich zwierząt nabywa usufructuarius jedynie na mocy ius gentium, a więc przez occupatio: 'fructuarius iure gentium suos facit'. Polara, akceptując co do zasady rekonstrukcję zaproponowaną przez Mommsena, odwołuje się do literalnego brzmienia scholii Stefana będącej podstawą do odtworzenia oryginalnej lektury tekstu Digestów (Bas. 16,1, 62) i proponuje następującą lectio tekstu: 'sed fructuario iure aut gentium suos facit'. Por. G. Polara, op. cit., s. 233-244.

38 'Digesta Iustiniani'. Digesta Justyniańskie..., II, s. 181. 
żyjącą w stanie naturalis libertas przysługiwało każdej osobie), lecz także odwołanie się do koncepcji fructus, jako tytułu nabywania przez użytkownika własności schwytanych na użytkowanym terenie dzikich zwierząt.

Jedną z możliwych interpretacji tego tekstu jest zaproponowana przeze mnie wcześniej interpretacja, zgodnie z którą Tryphoninus w principium tekstu D. 7,1,62 rozważał kazus rezerwatu, w którym na zagrodzonym obszarze żyły w swoim naturalnym środowisku różne gatunki dzikich zwierząt i w odniesieniu do którego juryści mogli mieć problemy z ustaleniem statusu prawnego trzymanych w nim zwierząt ${ }^{39}$. W zależności od konkretnych okoliczności stanu faktycznego, mogły one bądź być uznane za zwierzęta żyjące w stanie naturalis libertas (zwierzęta żyjące na wolności w lesie w momencie jego ogrodzenia), bądź za zwierzęta należące do właściciela rezerwatu (dzikie zwierzęta, które nabył on i umieścił w rezerwacie albo oswoił wyrabiając w nich animus revertendi). W odniesieniu do tych pierwszych tytułem nabycia ich własności jako res nullius byłaby occupatio, podczas gdy w drugim przypadku zwierzęta te mogłyby być potraktowane jako korzyść $\mathrm{z}$ gruntu a więc fructus fund $i^{40}$.

Inna możliwa do zaproponowania interpretacja tekstu D. 7,1,62 pr. zakłada, że zagadnienie, które było przedmiotem rozważań Tryphoninusa, było podobne do tego, które skłoniło wcześniej Cassiusa, a później również i Ulpiana, do refleksji nad prawem użytkownika do czerpania korzyści ekonomicznych z venatio, aucupio czy piscatio na gruncie oddanym w ususfructus i stanowiło wyraz wątpliwości, jakie mieli rzymscy iurisprudentes co do uznania polowania czy łowienia ryb za sposób wykonywania służebności użytkowania, w sytuacji, w której grunt stanowiący przedmiot użytkowania nie był wcześniej przeznaczony przez właściciela na potrzeby pastio villatica. Wątpliwości te zostają przez nich rozstrzygnięte na korzyść prawa użytkownika do czerpania korzyści ekonomicznych z dzikich zwierząt żyjących w stanie natury na

39 Za dowód na niejednoznaczność ich statusu może być uznany m.in. tekst Paulusa

D. 41,2,3,14 dotyczący posiadania feras, quae in silvis circumseptis vagantur.

40 Por. Z. Benincasa, Polowanie na dzikie zwierzęta..., s. 24-25. 
użytkowanym gruncie, zarówno poprzez okazjonalne polowanie i połów na gruncie, jak i poprzez założenie na gruncie zorganizowanych hodowli dzikich zwierząt, ptactwa czy ryb celem systematycznego i regularnego czerpania zysków z takich vivaria. W ten sposób formalnie sankcjonuje się polowanie i połów jako normalny sposób eksploatacji gospodarczej gruntu, a dziką zwierzynę, ptactwo i ryby jako pożytek, który przynosi fundus, zezwalając jednocześnie użytkownikowi na wykorzystanie naturalnych walorów gruntu oddanego w użytkowanie, zarówno w formie okazjonalnego polowania, jak i zorganizowanej hodowli dzikich zwierząt w vivaria, niezależnie od tego, czy właściciel gruntu wcześniej korzystał z takiej możliwości

Przyjmując taką perspektywę rozważań Tryphoninusa, należy uznać, że jurysta zastanawiał się nad możliwością polowania na dziką zwierzynę na gruncie oddanym w użytkowanie w sytuacji, w której grunt ten nie był przez jego właściciela oryginalnie przeznaczony na cele $p a-$ stio villatica i nie przynosił korzyści z polowania na dziką zwierzynę. W pierwszej części tekstu D. 7,1,62 pr. jurysta ten potwierdzałby prawo użytkownika do polowania na gruncie oddanym w użytkowanie i możliwość zawłaszczania upolowanej dzikiej zwierzyny, wykluczając tym samym jakiekolwiek roszczenia właściciela gruntu względem tej ostatniej. W dalszej części zaś, w której rozważa zagadnienie tytułu prawnego nabycia własności dzikiej zwierzyny, rozróżniałby dwa stany faktyczne: pierwszy, w którym grunt oddany w ususfructus nie był przeznaczony przez właściciela do celów myśliwskich i łowieckich, a użytkownik polował na nim okazjonalnie, nabywając własność dzikiej zwierzyny przez zawłaszczenie (iure gentium), oraz drugi, w którym użytkownik założył na gruncie vivaria i czerpał korzyści $z$ hodowanych w nich dzikich zwierząt w sposób zorganizowany i regularny, a więc dzika zwierzyna mogła być wyjątkowo potraktowana jako pożytek z gruntu (fructus).

Pierwszy paragraf tekstu D. 7,1,62 dotyczyłby zaś szczególnego przypadku oddania w użytkowanie gruntu, na którym właściciel założył uprzednio vivarium, i w tym miejscu Tryphoninus zastanawiałby się nad zakresem uprawnień przysługujących użytkownikowi w stosunku do takiego vivarium, uznając, że może również polować i zabijać znajdujące się w nim zwierzęta, pod warunkiem iż po wygaśnięciu użytkowania 
właściciel odzyska hodowlę liczącą dokładnie tyle samo zwierząt, ile liczyła ona w momencie ustanowienia służebności ${ }^{41}$.

Analiza zachowanych tekstów Digestów dotyczących dzikich zwierząt, ptaków i ryb żyjących w stanie naturalis libertas wskazuje, że nie mogły być one potraktowane za pożytek z gruntu, $\mathrm{z}$ wyjątkiem sytuacji, w której grunt ten był przeznaczony i zorganizowany na potrzeby venatio, aucupio czy piscatio, a więc znajdowały się na nim vivaria. W takim przypadku dzikie zwierzęta hodowane na zamkniętej przestrzeni pod kontrolą właściciela mogły być uznane za korzyść regularnie i systematycznie prokurowaną przez fundus. Możliwość rozszerzenia tego wyjątku również na zwierzęta żyjące w swoim środowisku naturalnym w rozległych rezerwatach nie jest już jednak jednoznaczna. Z jednej strony źródła literackie potwierdzają, że takie rezerwaty zakładane były dla czerpania korzyści ekonomicznych z hodowli dzikich zwierząt, $\mathrm{z}$ drugiej strony jednak widać trudności, jakie mieli juryści w uznaniu samego faktu ogrodzenia terenu, na którym żyły takie zwierzęta w stanie naturalis libertas za równoznaczny z nabyciem prawa własności takich zwierząt przez właściciela rezerwatu.

Niemożność uznania dzikich zwierząt żyjących w stanie natury za pożytek z gruntu nie wykluczała jednak możliwości uznania za fructus fundi dochodów z polowania i sprzedaży dzikiej zwierzyny. Zdaniem Cassiusa, nawet jeżeli sama schwytana zwierzyna i ptactwo oraz złowione ryby nie stanowiły pożytku z gruntu, ponieważ grunt ten nie był przeznaczony do celów myśliwskich i łowieckich, to jednak dochody, które mógł uzyskiwać użytkownik z tytułu okazjonalnej sprzedaży takich zwierząt czy wynajęcia osobom trzecim prawa do polowania na te zwierzęta, przypadały użytkownikowi.

\footnotetext{
41 D. 7,1,62,1: Si vivariis inclusae ferae in ea possessione custodiebantur, quando usus fructus coepit, num exercere eas fructuarius possit, occidere non possit? alias si quas initio incluserit operis suis vel post sibimet ipsae inciderint delapsaeve fuerint, hae fructuarii iuris sint? commodissime tamen, ne per singula animalia facultatis fructuarii propter discretionem difficilem ius incertum sit, sufficit eundem numerum per singula quoque genera ferarum finito usu fructu domino proprietatis adsignare, qui fuit coepti usus fructus tempore. Szerzej na temat tego tekstu por. Z. Benincasa, Polowanie na dzikie zwierzęta..., s. 22-24.
} 
Przedmiotem rozważań rzymskich jurystów była również możliwość wykonywania służebności użytkowania poprzez polowanie na gruncie, na którym ustanowiono ususfructus. Zarówno Tryphoninus, jak i Ulpian potwierdzają prawo użytkownika do polowania na gruncie oddanym w użytkowanie, niezależnie od tego, czy grunt ten był wcześniej przez jego właściciela przeznaczony do celów myśliwskich i łowieckich, zezwalając użytkownikowi zarówno na okazjonalne polowanie, jak i założenie na gruncie vivaria w celu czerpania stałych dochodów $\mathrm{z}$ hodowli dzikich zwierząt. Tym samym pod względem prawnym zrównuje się zyski pochodzące z hodowli dzikich zwierząt czy polowania na nie z dochodami, które tradycyjnie można było uzyskiwać wykorzystując grunt na cele rolnicze czy do hodowli zwierząt domowych ${ }^{42}$. W odniesieniu zaś do użytkowania vivarium założonego przez właściciela gruntu przed ustanowieniem służebności użytkowania, Tryphoninus przyznaje użytkownikowi dyskrecjonalne prawo do korzystania z takiej hodowli, zezwalając mu nie tylko na sprzedaż, lecz także polowanie i zabijanie zwierząt znajdujących się w hodowli, zobowiązując go jednocześnie do zwrotu właścicielowi hodowli liczącej tyle sztuk zwierząt, ile oryginalnie liczyło przekazane w użytkowanie vivarium.

Rozważania rzymskich iurisprudentes dotyczące polowania jako sposobu wykonywania służebności użytkowania, a także potraktowania dzikich zwierząt i dochodów z polowania i połowu jako fructus fundi stanowią dowód na ich żywe zainteresowanie przemianami społeczno-ekonomicznymi w końcu republiki i w początkach pryncypatu. Zmiana stylu życia rzymskich nobiles i rosnąca popularność spektakli z udziałem ferae bestiae zwiększyła istotnie znaczenie dzikich zwierząt jako potencjalnego źródła dochodu dla posiadaczy ziemskich i przekształciła skromnie przydomowe hodowle zakładane dla zaspokojenia potrzeb familia w duże vivaria i rozległe rezerwaty myśliwskie. Ta transformacja rzeczywistości społeczno-gospodarczej nie mogła pozostać niezauważona przez rzymskich jurystów, którzy w swoich rozważaniach

42 Por. Varro, De re rust. 3,2,10-11. Na temat legitymizacji nowej koncepcji villa związanej z pastio villatica, m.in. N. MORLEY, op. cit., 43-44; S. DiEDERICH, Römische Agrarhandbücher zwischen Fachwissenschaft, Literatur und Ideologie, Berlin 2007, s. 402-403. 
podejmują zagadnienie statusu prawnego zwierząt żyjących w vivaria i dochodów pozyskiwanych z polowania czy sprzedaży dzikich zwierząt, ptaków i ryb, nie tylko w celu ochrony interesów ekonomicznych właścicieli takich rezerwatów w relacji do coraz bardziej anachronicznej i nieprzystającej do rzeczywistości zasady wolności polowania na omnia quae terra mari caelo capiuntur, lecz także w celu umożliwienia użytkownikowi wykorzystania w pełni możliwości, jakie w nowej rzeczywistości dawało polowanie i hodowla dzikich zwierząt na gruncie oddanym w ususfructus.

OD 'RES NULLIUS' DO 'FRUCTUS FUNDI'. UPOLOWANA ZWIERZYNA ORAZ ZYSKI Z POLOWANIA I POŁOWU JAKO POŻYTEK Z GRUNTU W ROZWAŻANIACH RZYMSKICH JURYSTÓW

\section{Streszczenie}

W artykule omówione zostały teksty rzymskich jurystów podejmujące zagadnienie potraktowania dzikich zwierząt, ptactwa i ryb oraz dochodów pozyskiwanych z myślistwa i połowu jako fructus fundi. Co do zasady, dzika zwierzyna, ptactwo i ryby żyjące w stanie naturalis libertas nie mogły być potraktowane jako pożytek z gruntu, bowiem stanowiły element natury - res nullius, której własność mógł nabyć każdy przez zawłaszczenie. Zmianę przynosi dopiero schyłek republiki, kiedy to rosnący popyt na dzikie zwierzęta, ryby i ptactwo powoduje, że popularne staje się hodowanie ich dla zysku w zorganizowanych vivaria i rozległych rezerwatach. Te przemiany ekonomiczno-społeczne skłoniły rzymskich jurystów do rozszerzenia tradycyjnej koncepcji fructus fundi również na korzyści w postaci upolowanej zwierzyny, ptactwa i ryb oraz zysków z ich sprzedaży, jakie przynosił grunt przeznaczony na potrzeby venationes, a nawet na okazjonalne i nieregularne dochody, jakie mógł pozyskiwać użytkownik z tytułu sprzedaży i wynajmu upolowanej zwierzyny, ptactwa i złowionych ryb żyjących w stanie naturalis libertas na użytkowanym gruncie. 
From 'RES NUlliUs' to 'FrUCtUS FUndi': Roman JURISTS ON HUNTED Quarry and Gains the Hunters Obtained from the Chase as Profit DraWN From THE LAND

\section{Summary}

The article discusses the comments made by Roman jurists on game, wild fowl, and fish, and the profit to be obtained from hunting and fishing in the sense of fructus fundi. In principle, game, wildfowl, and fish living in a state of naturalis libertas could not be treated as profit obtained from the land, because they were part of the natural world and therefore res nullius, i.e. they did not belong to any specific proprietor and hence any person could acquire them. A change in this line of reasoning came in late Republican times, when a growing demand for wild animals, fowl, and fish contributed to the spread of vivaria and large game reserves, where animals were reared for commercial purposes. This socio-economic development induced jurists to extend the traditional concept of fructus fundi to cover the profit from hunting, fowling, and fishing, and the income from the sale of such quarry obtained on the land used for these purposes. The new ideas went as far as to include even the occasional profit a user could obtain from the sale or hire of wild animals, fowl or fish living in a state of naturalis libertas on a given tract of land, and caught during a hunt or a fishing expedition.

Słowa kluczowe: fructus fundi; pożytek; polowanie; venatio; vivarium. Keywords: fructus fundi; profit; hunting; venatio; vivarium.

\section{Bibliografia}

Amirante L., rec. z G. Polara, Le 'venationes'. Fenomeno economico e costruzione giuridica, «Iura» 34/1983, s. 255-262.

Anderson J.K., Hunting in the Ancient World, Berkeley-Los Angeles-London 1985.

Aymard J., La chasse romaine. Essai sur les chasses romaines des origines à la fin du siècle des Antonins (Cynegetica), Paris 1951.

Barra A., Gli 'incrementi fluviali' in diritto romano, «Paesi e uomini nel tempo. Collane di monografie di storia, scienze ed arti» 10/1998, s. 1-52. 
Benincasa Z., 'Si vivariis inclusae ferae'... Status prawny dzikich zwierząt żjacych $w$ vivaria i parkach myśliwskich $w$ prawie rzymskim, "Zeszyty Prawnicze»13.4/2013, s. 5-41.

Benincasa Z., 'Occupatio' jako sposób nabycia własności dziko żyjących zwierząt w prawie rzymskim, «Studia Iuridica» 59/2014, s. 9-39.

Benincasa Z., 'Accessio ab alluvione' $i$ 'reditus venationis et aucupii' jako 'fructus fundi'. Kilka uwag na marginesie PS. 3,6,22, "Zeszyty Prawnicze» 15.2/2015, s. 135-159.

Benincasa Z., Alcune riflessioni sulla libertà di caccia nel diritto romano: vivai e riserve di caccia, [w:] 'Mater familias'. Scritti romanistici per Maria Zabłocka, red. Z. BenincAsA, J. URBAniK, Warszawa 2016, s. 39-62.

Benincasa Z., Polowanie na dzikie zwierzęta jako jeden ze sposobów wykonywania służebności użytkowania w prawie rzymskim, "Studia i Materiały Ośrodka Kultury Leśnej» 15/2016, s. 9-29.

Benincasa Z., 'Illud quaesitum est, an fera bestia, quae ita vulnerata sit, ut capi possit, statim nostra esse intellegatur'. Zagadnienie ustalenia momentu zawłaszczenia dzikiego zwierzęcia $w$ rozważaniach rzymskich jurystów u schyłku republiki, [w:] 'Semper fidelis'. Prace dedykowane pamięci Profesora Janusza Sondla legendzie krakowskiego fakultetu prawniczego, red. D. MALEC, Ł. MarzeC, T. PAlmirski, Kraków 2017, s. 43-58.

BENINCASA Z., „Co się tyczy stworzeń, które z nawyku zwykły oddalać się i powracać...." - koncepcja 'animus revertendi' a wolność polowania na dzikie zwierzęta w prawie rzymskim, «Studia i Materiały Ośrodka Kultury Leśnej» 18/2019, s. 33-52.

CARdilli R., La nozione giuridica di 'fructus', Napoli 2000.

Castillo Pascual P., Die Kontroverse 'De alluvione' bei Gromatikern und Juristen, «eTopoi. Journal for Ancient Studies» 2/2012-2013, s. 1-23.

Crowther N.B., Sport in Ancient Times, Westport 2007.

Daube D., Doves and Bees, [w:] Droits de L'antiquité et sociologie juridique. Mélanges Henri Lévy-Bruhl, Paris 1959.

DIEDERICH S., Römische Agrarhandbücher zwischen Fachwissenschaft, Literatur und Ideologie, Berlin 2007.

Donahue Ch. JR, 'Animalia ferae naturae': Rome, Bologna, Leyden, Oxford and Queens County N.Y., [w:] Studies in Roman Law in Memory of A. Arthur Schiller, Leiden 1986, s. 39-63.

Epplett C., Animal 'spectacula' of the Roman Empire, Columbia 2001.

EPpletT C., The preparation of animals for Roman 'spectacula': 'vivaria' and their administration, «Ludica» 9/2003, s. 76-92. 
Epplett C., Roman Beast Hunts, [w:] P. Christesen, D.G. Kyle, A Companion to Sport and Spectacle in Greek and Roman Antiquity, Chichester 2014, s. 505-519.

Frier B.W., Bees and Lawyers, «Classical Journal» 78.2/1982-1983, s. 105-114.

FrIER B.W., Why did the Jurists change Roman Law? Bees and Lawyers revisited, «Index» 22/1994, s. 135-149.

Galloni P., Storia e cultura della caccia. Dalla preistoria a oggi, Roma 2000. García Garrido M.J., Derecho à la caza y 'ius prohibendi' en Roma, "AHDE» 26/1956, s. 269-336.

Giomaro A.M., Dall'instruere' all'instrumentum' e viceversa nell'economia della Roma antica, «Studi Urbinati» 62.1-2/2011.

Giudice C. LO, L'impiego degli animali negli spettacoli romani: 'venatio' e 'damnatio ad bestias', «Italies. Revue d'ètudes italiennes» 12/2008, s. 361-395.

Green C.M., Did the Romans hunt?, «Classical Antiquity»15.2/1996, s. 222-260. Grosso G., Usufrutto e figure affini nel diritto romano, Torino 1958.

Hausmaninger H., Celsus gegen Proculus, [w:] Festschrift Ulrich von Lübtow, Rheinfelsen 1991, s. 53-62.

Jallet-Huant M., La chasse dans l'Antiquité romaine, Montbel 2008.

Kańska K., Mańko R., 'Alluvio' i 'mutatio alvei'. Zastosowanie reguł rzymskich $w$ prawie międzynarodowym publicznym, «Studia Iuridica» 41/2003, s. 136-140.

LAMBERTINI R., 'Lapis crescere potest'. I frutti del regno minerale, "Archivio Giuridico» 204/1994, s. 97-165.

Lane Fox R.J., Ancient Hunting: from Homer to Polybios, [w:] Human Landscapes in Classical Antiquity. Environment and Culture, red. J. SALmon, G. SHIPLEY, New York 1996, s. 128-153.

LOMBARDI G., Libertà di caccia e proprietà privata in diritto romano, «BIDR» 12-13/1948, s. 273-343.

LoNGo O., Le regole della caccia nel mondo greco-romano, «Aufidus» 1/1987, s. 59-91.

MacKinnon M., Supplying Exotic Animals for the Roman Amphitheatre Games. New Reconstructions combining Archeological, Ancient Textual, Historical and Etnographic Data, «Mouseion» 3.6/2006, s. 137-161.

MacKinnon M., Hunting in Roman Antiquity, [w:] The Oxford Handbook of Animals in Classical Thought and Life, red. G. Lindsay CAMPBell, Oxford 2014, s. 207-213.

Maddalena P., Gli incrementi fluviali nella visione giurisprudenziale classica, Napoli 1970. 
Maganzani L., Gli incrementi fluviali in Fiorentino VI inst. (D. 41.1.16), «SDHI» 59/1993, s. 207-258.

Maganzani L., I fenomeni fluviali e la situazione giuridica del suolo rivierasco: tracce di un dibattito giurisprudenziale, «Ius» 44/1997, s. 343-390.

MANFREdini A.D., „Chi caccia e chi è cacciato”. Cacciatore e preda nella storia del diritto, Torino 2006.

Manfredini A.D., 'Un'iniuria' che non c'è, [w:] Diritto romano, tradizione romanistica e formazione del diritto europeo, red. L. VACCA, Milano 2008, s. $181-202$.

Mantovani D., I giuristi, il retore e le api. 'Ius controversum' e 'natura' nella 'Declamatio Maior XIII', [w:] Testi e problemi del giusnaturalismo romano, red. D. Mantovani, A. Schiavone, Pavia 2007, s. 323-385.

MARTini R., Sui frutti delle'venationes', «Labeo» 32/1986, s. 215-218.

Metro A., Un'ipotesi sul regime giuridico dell' 'insula in flumine nata', «Iura» 51/2000, s. 47-53.

Morley N., Frugality and Roman economic thinking in Varro's Rerum rusticarum, «I quaderni del Ramo d'Oro on line» 10/2018, s. 41-54.

NiCZYPORUK P., Rzymskie regulacje pierwowzorem wspótczesnych rozwiązań prawnych $w$ zakresie pszczelarstwa i bartnictwa, [w:] Prawne aspekty prowadzenia działalności bartnej. Wybrane zagadnienia, red. E.K. СzECH, Białystok 2015, s. 17-35.

Negri G., Diritto minerario romano, I, Milano 1985.

Palmirski T. (red.), 'Digesta Iustiniani'. Digesta Justyniańskie. Tekst i przekład, II, Kraków 2013.

Palmirski T. (red.), 'Digesta Iustiniani'. Digesta Justyniańskie. Tekst i przekład, IV, Kraków 2014.

Pavese M.P., 'Fundus cum vadis et alluvionibus'. Gli incrementi fluviali fra documenti della prassi e riflessione giurisprudenziale romana, Roma 2004.

Polara G., Le 'venationes'. Fenomeno economico e costruzione giuridica, Milano 1983.

Polojac M., Gaius, Hadzic and 'occupatio' of wild animals - classical Roman law in the Serbian Civil Code, [w:] R. vAN DEN BERGH et al., 'Meditationes de iure et historia'. Essays in honour of Laurens Winkel, Fundamina 20.2/2014, s. 738-746.

RAGA E., Réflexions sur le rapport ville/campagne dans l'Antiquité tardive au travers de quelques discours sur la chasse, "Revue belge de philologie et d'histoire» 89.2/2011, s. 659-668. 
SARgenti M., Tre osservazioni sul regime degli incrementi fluviali, «SDHI» 23/1957, s. 352-357.

SŁAPEK D., Gladiatorzy i polityka. Igrzyska w okresie późnej Republiki Rzymskiej, Wrocław 1995.

SŁAPEK D., Sport i widowiska w świecie antycznym. Kompendium, Kraków-Warszawa 2010, s. 703-711.

ŚWIRgoŃ-SKок R., Nieruchomość i zasady akcesji według prawa rzymskiego, Rzeszów 2007.

Trinquier J., Vendries Ch., (red), Chasses antiques. Pratiques et représentations dans le monde gréco-romain (IIIe s. av.-IVe s. apr. J.-C.). [w:] Actes du colloque international de Rennes (Université Rennes II, 20-21 septembre 2007), (Archéologie et Culture), Rennes 2009. 